\title{
Competitive sorption of nickel, copper, lead and cadmium on okra leaves (Abelmoschus esculentus)
}

\author{
Khaskheli M.I. ${ }^{1,}{ }^{,}$, Memon S.Q.1, Jatoi W.B. ${ }^{2}$, Chandio Z.A. ${ }^{1}$, Shar G.K. ${ }^{2}$, Malik A. ${ }^{1}$ and Khan S. ${ }^{3}$ \\ ${ }^{1} \mathrm{M}$. A. Kazi Institute of Chemistry, University of Sindh, Jamshoro 76080, Pakistan. \\ ${ }^{2}$ Institute of Chemistry, Shah Abdul Latif University Khairpur Mirs, Pakistan. \\ ${ }^{3}$ Molecular Biology (Genetics) Laboratory Medical Research Centre, LUMHS, Jamshoro, Pakistan \\ Received: 22/02/2016, Accepted: 11/04/2017, Available online: 26/09/2017 \\ *to whom all correspondence should be addressed: \\ e-mail: kumailmazhar@gmail.com
}

\section{Abstract}

In this study, potential of okra leaves for the removal of $\mathrm{Ni}(\mathrm{II}), \mathrm{Cu}(\mathrm{II}), \mathrm{Pb}$ (II) and $\mathrm{Cd}(\mathrm{II})$ from the mixed metal aqueous solution were evaluated. The data were analyzed by Freundlich, Langmuir, D-R, Flory-Huggins and Halsey adsorption models. Pseudo first order rate, Pseudo second order rate, Morris-Weber and Elovich equations were employed to understand the kinetics of the reaction. The characterization of the adsorbent was carried out by EDX and FTIR techniques. The order of maximum metal uptake calculated by $\mathrm{D}-\mathrm{R}$ isotherm was $\mathrm{Cu}(\mathrm{II})>\mathrm{Pb}(\mathrm{II})>\mathrm{Cd}(\mathrm{II})$ and $\mathrm{Ni}(\mathrm{II}), 453 \mathrm{mg} \mathrm{g}^{-1}, 81 \mathrm{mg} \mathrm{g}^{-1}, 13.82 \mathrm{mg} \mathrm{g}^{-1}$ and $1 \mathrm{mg} \mathrm{g}^{-1}$ respectively, with the energy of adsorption in the range of 9-15 for $\mathrm{Ni}(\mathrm{II})$ and $\mathrm{Cd}(\mathrm{II})$ expected for the ion exchange nature of adsorption and 7-8 for $\mathrm{Cu}$ (II) and $\mathrm{Pb}$ (II) showing the physical nature of adsorption. The calculated thermodynamic parameters like Gibbs free energy and enthalpy change demonstrate that adsorption process was spontaneous and endothermic in nature. Further it was observed that all four metal ions could be adsorbed at $\mathrm{pH}$ 6 with detection limits of $0.04-0.1 \mu \mathrm{g} \mathrm{L}^{-1}$. The method was successfully applied for the removal of these metal ions from the ground water, tap water and wastewater samples collected from different areas of Pakistan.

Keywords: Okra leaves; Removal; Metals; D-R isotherm; Kinetics

\section{Introduction}

Ground water contamination with heavy metals wastes is the greatest threat for government agencies, industry and communities (Jaeyoung et al., 2009). Industrial activities and the processing of ore mining are the major sources through which these toxic metals have been introduced into the environment (Fuller et al., 2002). Literature survey indicates that $\mathrm{Ni}(\mathrm{II}), \mathrm{Cu}(\mathrm{II}), \mathrm{Cd}(\mathrm{II})$ and $\mathrm{Pb}(\mathrm{II})$ are some of the potential pollutants of the environment. Cadmium, nickel and lead are known as toxic heavy metals, posing a serious threat to plant, animal, human and environment (Ashenef, 2014). According to W.H.O, maximum contamination levels of copper, cadmium, nickel and lead in drinking water are
$2 \mathrm{mg} \mathrm{g}^{-1}, 0.003 \mathrm{mg} \mathrm{g}^{-1}, 0.07 \mathrm{mg} \mathrm{g}^{-1}$ and $0.01 \mathrm{mg} \mathrm{g}^{-1}$ respectively (W.H.O, 2011). Lead heads the list of environmental threats because even at extremely low concentrations it causes brain damage in children (Ahmedna et al., 2004). Cadmium is non-essential, nonbeneficial and recognized as an occupational health hazard for many decades and increasing number of studies have shown early adverse health effects on the kidney (Kefela et al., 1999; Chandio et al., 2013). Cadmium ions are not biodegradable and easily accumulate in human tissues (Evangelin et al., 2014). The inhalation of nickel and its compounds can lead to serious problems, including respiratory cancer, skin allergies, dermatitis, lung fibrosis, headaches, nausea, vomiting, chest pain, dry cough and shortness of breath (Chandio et al., 2013). The toxic effects of copper are well documented by Sobecka (Sobecka, 2001).

Chemical precipitation, reverse osmosis, ion-exchange, filtration and evaporative recovery are most commonly using methods and effective for the treatment of liquid effluents containing high concentration of metal ions. However, these technologies are usually expensive and become inefficient for treatment of effluents containing metal ions in the range of $100 \mathrm{mg} \mathrm{L}^{-1}$ (Suman et al., 2008). Over the last few years, adsorption has been shown to be an economically and environmentally feasible method for removal of metal ions from ground water and wastewater (Khaskheli et al., 2011). The biggest barrier in the application of this process by the industries is the high cost of adsorbents presently available for commercial use. It is, therefore, important to explore new adsorbents for metals removal and recovery from such effluents, and thus reduce the concentration of these metal ions to the safe levels.

Okra (Abelmoschus esculentus), a flowering plant belongs to mallow family Malvaceae, is a tropical perennial crop growing 3 to 6 feet tall. It is believed to have originated in Ethiopia. In recent years, it has become an important commercial crop, especially in south, where thousands of tons of the pods are grown (Olajide, 2009). In current study an effort has been made to develop an efficient, cheap and environmental friendly method to remove nickel, copper, 
lead and cadmium using okra leaves as an adsorbent. Table 1 shows a comparison of the capacities of different sorbent materials with proposed sorbent. It can be shown that okra leaves have comparable capacity values with most of the sorbents reported in the literature. In order to check the practical applicability of a method it has been used for removal of all four metal ions from real water systems.

Table 1. Comparison of sorption capacities of various sorbents for $\mathrm{Cu}(\mathrm{II}), \mathrm{Cd}(\mathrm{II}), \mathrm{Ni}(\mathrm{II})$ and $\mathrm{Pb}(\mathrm{II})$

\begin{tabular}{|c|c|c|c|c|c|c|c|c|c|c|}
\hline \multirow{2}{*}{$\begin{array}{c}\text { Adsorbent } \\
\text { Metals }\end{array}$} & \multicolumn{4}{|c|}{$\mathrm{pH}$} & \multicolumn{4}{|c|}{$\begin{array}{l}\text { Capacity }\left(\mathrm{mg} \mathrm{g}^{-1}\right) \\
\text { Based on Langmuir isotherm }\end{array}$} & \multirow[t]{2}{*}{ Applications } & \multirow[t]{2}{*}{ References } \\
\hline & $\begin{array}{c}\mathrm{Pb}(\mathrm{II} \\
)\end{array}$ & $\begin{array}{c}\mathrm{Cd}(I I \\
)\end{array}$ & $\begin{array}{c}\mathrm{Cu}(\mathrm{II} \\
)\end{array}$ & $\mathrm{Ni}(\mathrm{II})$ & $\mathrm{Pb}(\mathrm{II})$ & $\mathrm{Cd}(\mathrm{II})$ & $\mathrm{Cu}(\mathrm{II})$ & $\mathrm{Ni}(I I)$ & & \\
\hline Wheat bran & 5 & 5 & 5 & 5 & 62.0 & 21.0 & 15.0 & 12.0 & Not applied & $\begin{array}{l}\text { Farajzadeh and Monji, } \\
2004\end{array}$ \\
\hline Barley straw & 6 & & 6.6 & & 23.2 & - & 4.64 & - & Not applied & Pehilvan et al., 2009 \\
\hline $\begin{array}{l}\text { Tartaric acid modified } \\
\text { rice husk }\end{array}$ & - & - & - & - & 108 & - & 29.0 & - & Not applied & Wong et al., 2003 \\
\hline Coffee husk & - & 6 & 7 & - & - & 6.85 & 7.50 & - & Not applied & Oliveira et al., 2008 \\
\hline Waste black tea & - & - & - & 5 & - & - & - & 90.91 & wastewater & $\begin{array}{l}\text { Malakahmad et al., } \\
2016\end{array}$ \\
\hline $\begin{array}{l}\mathrm{HCl} \text { treated oak } \\
\text { sawdust }\end{array}$ & 7 & 7 & 7 & 7 & - & - & 3.60 & 3.37 & Waste water & Argun et al., 2007 \\
\hline Dairy sludge & - & - & - & - & 149 & 66.7 & - & - & Not applied & Sassi et al., 2010 \\
\hline Treated Geobacillus & 4.5 & 6 & 7.5 & - & 32.3 & 42.9 & 50 & - & $\begin{array}{c}\text { Industrial } \\
\text { waste water }\end{array}$ & Chatterjee et al., 2010 \\
\hline marine algae & 6 & 6 & 6 & - & 232.6 & 88.5 & 92.6 & - & Waste water & Feng and Jatoi, 2004 \\
\hline $\begin{array}{l}\text { Functionalized HLS } \\
\text { biomass }\end{array}$ & - & - & - & - & - & 52.8 & - & 23.6 & Not applied & Panda et al., 2008 \\
\hline Pristine biomass & - & - & - & - & - & 35.0 & - & 15.7 & Not applied & \\
\hline $\begin{array}{l}\text { Orange peel cellulose } \\
\text { Unmodified }\end{array}$ & $5-7$ & - & - & - & - & 55.1 & - & 27.0 & Not applied & Li et al., 2008 \\
\hline Grape stalk waste & 5.5 & 5.5 & 5.5 & 5.5 & 49.9 & 27.9 & - & - & Not applied & Martinez et al., 2006 \\
\hline Hazelnut shell & - & - & - & - & 16.23 & 5.42 & - & 3.83 & & \\
\hline Almond shell & - & - & - & - & 3.43 & 3.18 & - & 3.11 & Not applied & Bulut and Tez, 2007 \\
\hline Holly oak(stem) & - & - & - & - & 0.75 & 0.36 & 0.21 & 0.58 & Not applied & $\begin{array}{l}\text { Parsad and Freltas, } \\
\qquad 2000\end{array}$ \\
\hline Brewery biomass & 5 & 5.5 & 5.5 & - & 96.4 & 14.3 & 48.9 & - & Not applied & Kim et al., 2005 \\
\hline Sawdust of walnut & - & - & - & - & 6.66 & 4.90 & - & 2.79 & $\begin{array}{l}\text { Waste water } \\
\text { Mine water, }\end{array}$ & Bulut and Tez, 2007 \\
\hline $\begin{array}{c}\text { Sawdust of deciduous } \\
\text { trees }\end{array}$ & $3.5-5.5$ & $5-$ & - & - & - & 3.50 & 9.90 & 4.60 & $\begin{array}{c}\text { Electroplating } \\
\text { water, metal } \\
\text { industry }\end{array}$ & Bozic et al., 2009 \\
\hline $\begin{array}{l}\text { Phaseolus aureus hull } \\
\text { carbon }\end{array}$ & 6 & 8 & 7 & - & 21.8 & 15.7 & 19.5 & - & Not applied & Rao et al., 2009 \\
\hline Olive stone waste & $5.5-6$ & - & - & - & 9.26 & 7.73 & 2.02 & 2.13 & Not applied & Fiol et al., 2006 \\
\hline $\begin{array}{c}\mathrm{NaOH} \text { treated Reed } \\
\text { biomass }\end{array}$ & 4 & 7 & 7 & 7 & 0.083 & 0.019 & 0.156 & 0.135 & Not applied & Southichak et al., 2006 \\
\hline $\begin{array}{c}\text { *Okra leave (present } \\
\text { work) }\end{array}$ & 6 & 6 & 6 & 6 & 81.0 & 18.8 & 453 & 2.16 & $\begin{array}{l}\text { Drinking and } \\
\text { waste water }\end{array}$ & This study \\
\hline
\end{tabular}

\section{Experimental}

\subsection{Materials and methods}

All chemicals used were of analytical grade and supplied by Merck (Darmstadt, Germany). A stock standard solution of all four metal ions was prepared by dissolving the appropriate amount of their salts in deionized water (conductivity <0.5_Scm-1). Buffer solutions of $\mathrm{pH} 1-3,4-6$ and 7-9 were prepared by mixing appropriate ratios of $0.1 \mathrm{M} \mathrm{HCl}$ and $\mathrm{KCl}, 0.5 \mathrm{M}$ acetic acid and sodium acetate and $0.5 \mathrm{M}$ ammonia and $\mathrm{NH}_{4} \mathrm{Cl}$ solutions respectively.

\subsection{Chemical analysis}

Perkins-Elmer Atomic Absorption Spectrophotometer (AA800 ) was used to quantify metal ions using recommended conditions. All pH measurements were carried out by Thermo Scientific Orion 5 Star ( $\mathrm{pH}$. ISE. Cond. DO Benchtop, 8102BNUWP; Made in USA) PH-meter. Shaking Incubator Model 1-40000 Irmeco GmbH (Geesthacht/Germany) was

used for batch experiments. Peristaltic pump (Gilson, Made in France) was used for column study.

\subsection{Batch sorption study of $\mathrm{Ni}(\mathrm{II}), \mathrm{CU}(\mathrm{II}), \mathrm{Cd}(\mathrm{II})$ and $\mathrm{Pb}(\mathrm{II})$}

A weighed amount of Okra leaves was equilibrated with 20 $\mathrm{mL}$ solution containing $10 \mathrm{mg} \mathrm{mL}^{-1}$ of each $\mathrm{Ni}(\mathrm{II}), \mathrm{Cu}(\mathrm{II})$, $\mathrm{Cd}(\mathrm{II})$ and $\mathrm{Pb}(\mathrm{II})$ at $\mathrm{pH} 6$ and ionic strength $\left(0.001 \mathrm{~mol} \mathrm{~L}^{-1}\right)$ at $25 \pm 1^{\circ} \mathrm{C}$. The sorbent was filtered and the equilibrium concentration was determined.

\subsection{Sorption of metal ions (Ni (II), CU(II), Cd(II) and Pb(II)) by column method}

A fixed bed study was carried out in a glass column made up of glass. A glass column of $18 \mathrm{~cm}$ length and $1.2 \mathrm{~cm}$ diameter was selected for the study. Small amount of glass wool was placed in the bottom to avoid the wastage of sorbent from the lower end of the column. Then slurry in water of $0.5 \mathrm{~g}$ of sorbent was poured and column filled up to the $2.5 \mathrm{~cm}$. pH 6 maintained metals ion solution was pumped through the embedded column by peristaltic 
pump controlling the flow rate $1-6 \mathrm{~mL} \mathrm{~min}^{-1}$. The passing of the solution at an optimized flow rate, continued till no sorption of metal ion occurred or biomass in the column was fully saturated with metal ions means breakthrough was achieved. Then a suitable amount of leaching agent $\left(\mathrm{H}_{2} \mathrm{SO}_{4}\right)$ was eluted through the column having metal loaded sorbent. Consequently, metal analysis of eluted sample solutions collected at regular intervals of time after sorption and desorption were done with an Atomic Absorption spectrometer. Column studies were conducted at room temperature $\left(25^{\circ} \mathrm{C}\right)$. Finally, breakthrough curves were drawn from the observed results.

\section{Data manipulation}

The percent sorption of all four metal ions was determined using the following equation: \%Sorption $=\frac{C_{0}-C_{f}}{C_{0}}$ (Bazrafshan et al., 2012).

Where
$\mathrm{C}_{0}=$ Concentration of solution before sorption $\left(\mathrm{mol} \mathrm{L}^{-1}\right)$

$\mathrm{C}_{\mathrm{f}}=$ Concentration of solution after sorption $\left(\mathrm{mol} \mathrm{L}^{-1}\right)$

\section{Results and discussion}

\subsection{Characterization of sorbent}

\subsubsection{Energy Dispersive X-ray Analysis (EDX) of metal loaded okra leaves}

The surface study of okra leaves before and after the sorption of metal ions was carried out. Both figures Fig.1a and Fig. 1b show the elemental analysis of okra leaves before and after the sorption respectively. In Fig.1a okra leaves sorbent contains a number of elements including carbon, oxygen, sodium, aluminum and calcium. While peaks of $\mathrm{Cu}(\mathrm{II}), \mathrm{Cd}(\mathrm{II}), \mathrm{Ni}(\mathrm{II})$ and $\mathrm{Pb}(\mathrm{II})$ appeared in the EDX spectrum of okra leaves (Fig. 1b) shows the retention of these metal ions.

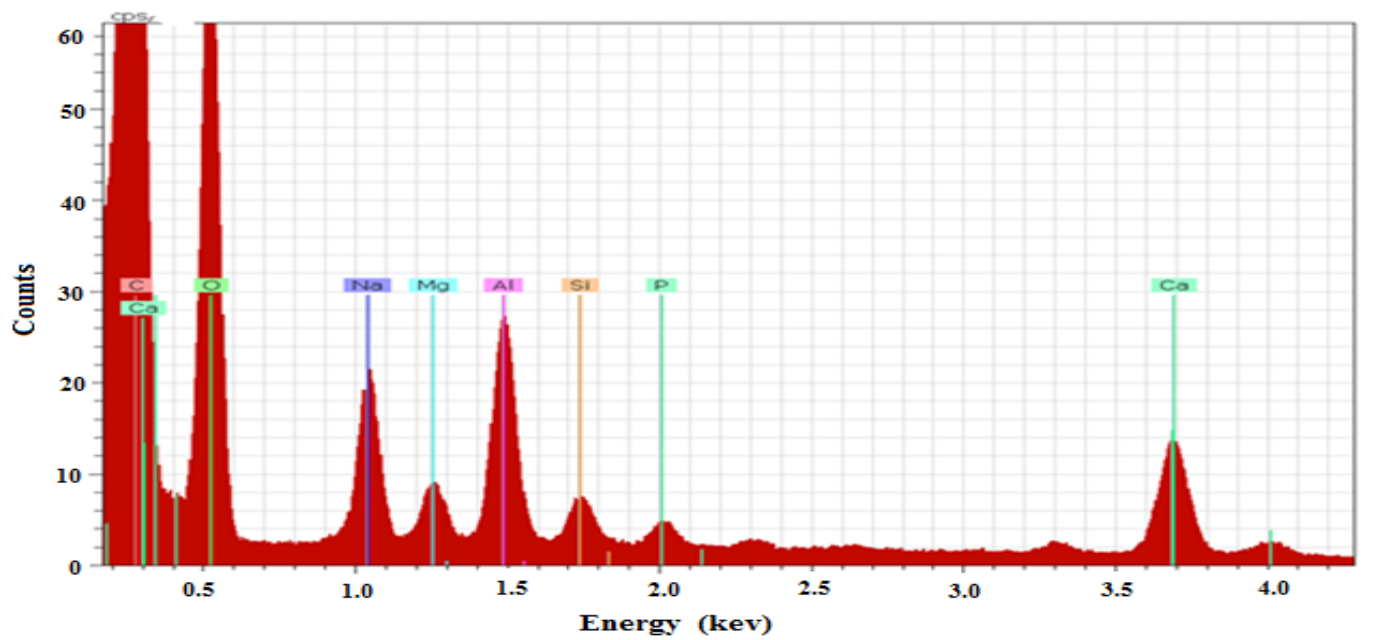

Figure 1a. EDX of Okra leaves before copper(II), cadmium(II), nickel(II) and lead(II) retention

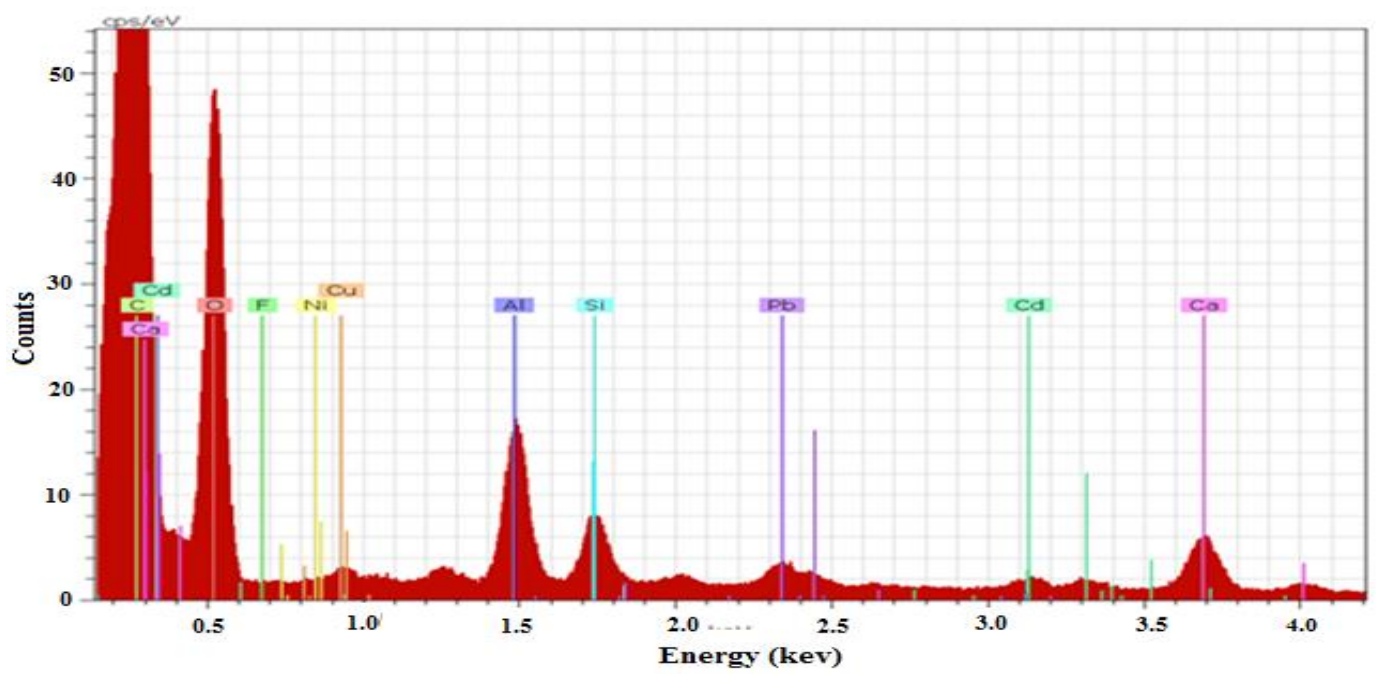

Figure 1b. EDX of Okra leaves after copper(II), cadmium(II), nickel(II) and lead(II) retention

\subsubsection{Fourier Transform infrared spectroscopy (FT-IR) analysis}

In order to understand the mechanism of interaction between functional groups present in the okra leaves sorbent and metal ions, the FT-IR analysis technique was 
employed (Silverstein and Webster, 1998). The spectra of the unloaded and metal ions loaded sorbents were taken in the range of $500-4000 \mathrm{~cm}^{-1}$ wave number. The spectra of okra leaves sorbent before and after the metal ions sorption are shown in Fig. 2. The bands at $2847-2921 \mathrm{~cm}^{-1}$, $1589-1634 \mathrm{~cm}^{-1}, 1409-1421 \mathrm{~cm}^{-1} 1303-1319 \mathrm{~cm}^{-1}, 1000-$ $1237 \mathrm{~cm}^{-1}$ and $699 \mathrm{~cm}^{-1}$ were attributed to $\mathrm{H}-\mathrm{C}-\mathrm{H}$ asymmetric and symmetric stretching (alkane), $\mathrm{C}=\mathrm{N}$ stretching (oxime), $\mathrm{O}-\mathrm{H}$ bending (carboxylic acid), $\mathrm{N}=\mathrm{O}$ bending (nitro group), $\mathrm{C}-\mathrm{O}-\mathrm{C}$ stretching (ethers) and $\mathrm{C}-\mathrm{H}$ bending (alkenes).
The shift of peaks for copper at $\left(2913 \mathrm{~cm}^{-1}, 1605 \mathrm{~cm}^{-1}, 1413\right.$ $\left.\mathrm{cm}^{-1}, 1311 \mathrm{~cm}^{-1} \& 1225 \mathrm{~cm}^{-1}\right)$, cadmium $\left(2913 \mathrm{~cm}^{-1}, 1413\right.$ $\left.\mathrm{cm}^{-1} \mathrm{~cm}^{-1} \& 1225 \mathrm{~cm}^{-1}\right)$, nickel $\left(2847 \mathrm{~cm}^{-1}, 1605 \mathrm{~cm}^{-1}, 1413\right.$ $\left.\mathrm{cm}^{-1}, \& 1311 \mathrm{~cm}^{-1}\right)$ and lead $\left(2913 \mathrm{~cm}^{-1}, 2847 \mathrm{~cm}^{-1}, 1605 \mathrm{~cm}^{-}\right.$ $1,1413 \mathrm{~cm}^{-1}, 1311 \mathrm{~cm}^{-1} \& 1225 \mathrm{~cm}^{-1}$ ) were observed. The disappearance of peak at $996 \mathrm{~cm}^{-1}$ and emergence of new peak at $1000-1012 \mathrm{~cm}^{-1}$ in Fig. 2 was also analyzed. These changes in vibrational frequencies and appearance and disappearance of peaks indicate that $\mathrm{C}-\mathrm{H}$ (alkane), $\mathrm{N}-\mathrm{H}$ (amide), $\mathrm{O}-\mathrm{H}$ (carboxylic acid), $\mathrm{N}=\mathrm{O}$ (nitro group), $\mathrm{C}-\mathrm{O}-\mathrm{C}$ (ether) and $\mathrm{C}-\mathrm{H}$ (alkene) functional groups are involved in the metal ions binding.

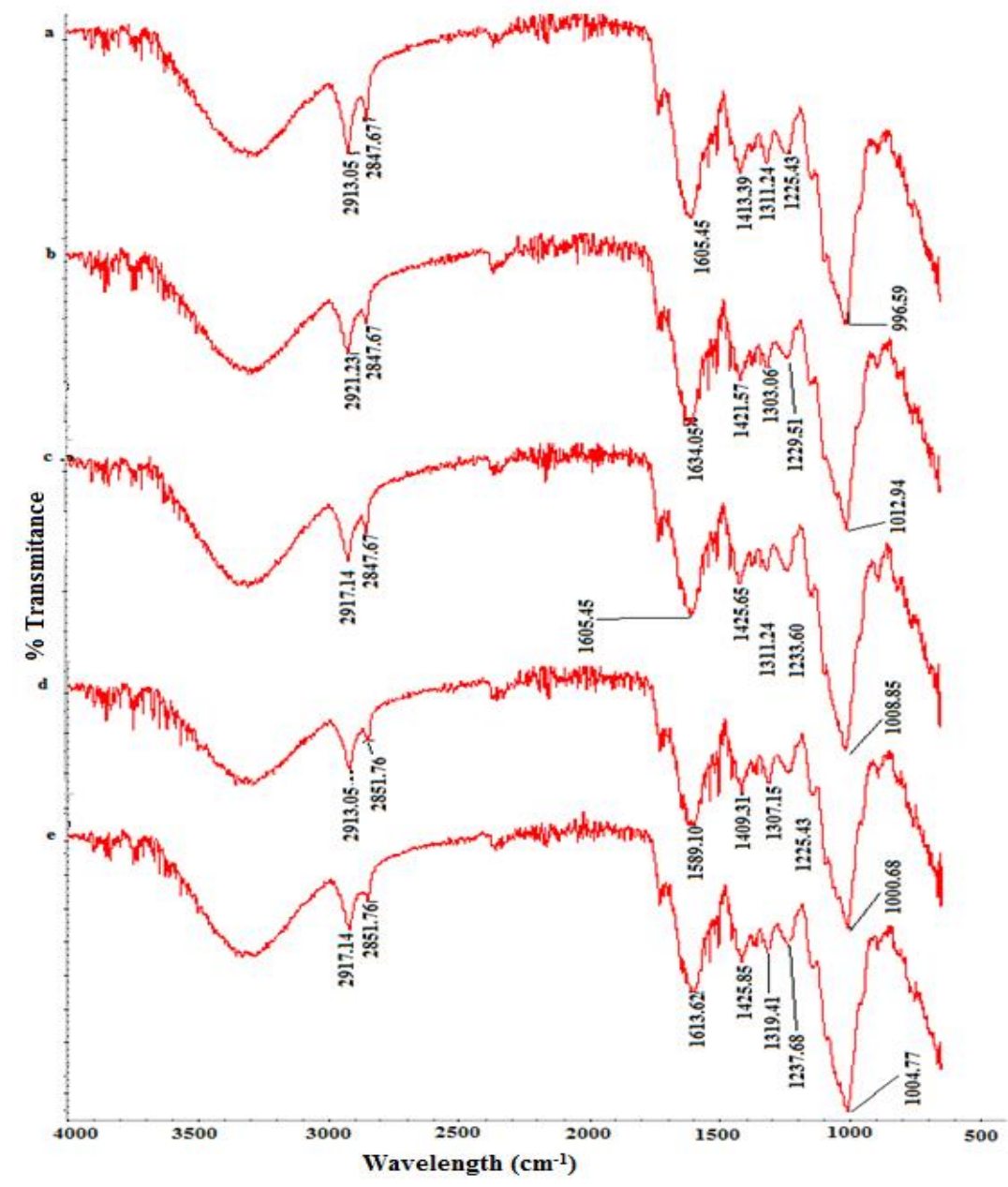

Figure 2. (a) FT-IR spectra of okra leaves (b) $\mathrm{Cu}$ (II) (c) $\mathrm{Cd}$ (II) (d) $\mathrm{Ni}$ (II) and (e) Pb(II) loaded

\subsection{Effect of $\mathrm{pH}$}

The $\mathrm{pH}$ of the metal ion solution can affect the surface charges of the sorbent, degree of ionization of pollutants and dissociation of functional groups at active sites (Bazrafshan et al., 2013). The study of pH identifies binding sites and the type and amount of species sorbed onto the surface okra leave sorbent. The effect of pH (Fig. 3) of $\mathrm{Ni}(\mathrm{II})$, $\mathrm{Cu}(\mathrm{II}), \mathrm{Cd}(\mathrm{II})$ and $\mathrm{Pb}(\mathrm{II})$ ions solution was optimized with respect to the amount of metal ions loaded onto the sorbent surface.
The initial increase in sorption of all four metal ions was observed with increasing $\mathrm{pH}$ up to 3 . Copper and lead showed a similar behavior after $\mathrm{pH} 3$ and their sorption remains constant up to $\mathrm{pH} 6$. Both metals showed a little decrease at $\mathrm{pH} 7$ and then increases at $\mathrm{pH}$ 8-9. Whereas the sorption of nickel was constant up to $\mathrm{pH} 7$ and then increased drastically at $\mathrm{pH}$ 8-9. Cadmium showed completely different behavior than rest of three metals. There was a continuous increase in percent sorption with increasing $\mathrm{pH}$. The different behavior of sorption of metal 
ions may be due to the formation of different species at different $\mathrm{pH}$ values.

The main specie of $\mathrm{Ni}(\mathrm{II})$ at $\mathrm{pH} 8$ is $\mathrm{Ni}^{2+}$ and at $\mathrm{pH} 10$ the dominant species of $\mathrm{Ni}(\mathrm{II})$ ions would be $\mathrm{Ni}(\mathrm{OH})_{2}(60 \%)$, $\mathrm{Ni}^{2+}(18 \%), \mathrm{Ni}(\mathrm{OH})^{+}(11 \%)$ and $\mathrm{Ni}(\mathrm{OH})^{3-}(10 \%)$. At $\mathrm{pH} 9$ the dominant species of $\mathrm{Cu}(\mathrm{II})$ would be $\mathrm{Cu}_{2}(\mathrm{OH})_{2}$ (60\%), $\mathrm{Cu}(\mathrm{OH})^{+}(\sim 25 \%), \mathrm{Cu}(\mathrm{OH})_{2}(10 \%)$ and $\mathrm{Cu}^{2+}(\sim 4 \%)$ which would change to $\mathrm{Cu}(\mathrm{OH})_{2}(40 \%), \mathrm{Cu}(\mathrm{OH})^{3-}(37 \%), \mathrm{Cu}(\mathrm{OH})^{+}(12 \%)$, $\mathrm{Cu}(\mathrm{OH})_{2}{ }^{2+}(10 \%)$ and $\mathrm{Cu}(\mathrm{OH})_{4}{ }^{2-}(5 \%)$ at $\mathrm{pH} 10$ (Memon et al., 2007).

Up to $\mathrm{pH} 7$ the main species of $\mathrm{Pb}(\mathrm{II})$ is $\mathrm{Pb}^{2+}(>80 \%)$ and at $\mathrm{pH} 8$ the dominant species of $\mathrm{Pb}(\mathrm{II})$ ions would be $\mathrm{Pb}^{2+}$ $(\sim 50 \%), \mathrm{Pb}(\mathrm{OH})^{+}(\sim 5 \%), \mathrm{Pb}_{3}(\mathrm{OH})_{2}{ }^{+4}(\sim 3 \%)$, and $\mathrm{Pb}(\mathrm{OH})_{2}$ ( 1\%) (Memon et al., 2005). Cadmium is the metal having $\sim 100 \%$ of $\mathrm{Cd}$ as $\mathrm{Cd}^{2+}$ ( 100) up to $\mathrm{pH} 8$ (Memon et al., 2007) this may explain the reason for its different behavior from all three metal ions. Keeping in view the hydroxyl species of metal ions, $\mathrm{pH} 6$ has been selected as a medium of sorption. Therefore, the hydroxide retention mechanism can be avoided.

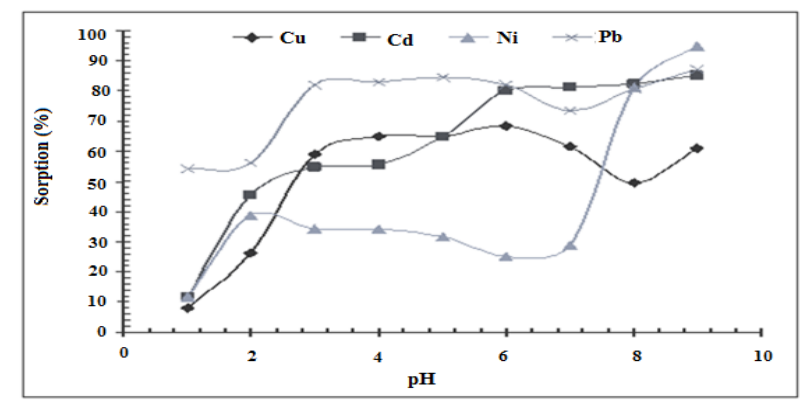

Figure 3. Effect of $\mathrm{pH}$ on removal of $\mathrm{Cu}(\mathrm{II}), \mathrm{Cd}(\mathrm{II}), \mathrm{Ni}(\mathrm{II})$ and $\mathrm{Pb}(\mathrm{II})$ on okra leaves

\subsection{Amount of sorbent}

In sorption process the dosage of sorbent considerably affect the sorption efficiency of the sorbent. The amount of sorbent determines the uptake capacity of okra sorbent for the competitive sorption of various metal ions. The trend of sorption of copper, cadmium, nickel and lead was similar. Initially as amount of sorbent was increased, 30$80 \%$ sorption was increased at $0.1 \mathrm{mg}$ per $10 \mathrm{~mL}$ and then smaller decrease or nearly constant sorption was observed as amount of sorbent was increased. The increase in sorption was due to the availability of the more active sites for the sorption of $\mathrm{Cu}(\mathrm{II}), \mathrm{Cd}(\mathrm{II}), \mathrm{Ni}(\mathrm{II})$ and $\mathrm{Pb}(\mathrm{II})$, while the decrease in sorption may be attributed to the accumulation of sorbent. Accumulation decreases the sorption active sites (Rojas et al., 2005).

\subsection{Uptake of $\mathrm{Ni}(\mathrm{II}), \mathrm{Cu}(\mathrm{II}), \mathrm{Cd}(\mathrm{II})$ and $\mathrm{Pb}(\mathrm{II})$ as a function of time}

The contact time between sorbate and sorbent is one of the most important design parameters that affect the performance of adsorption process (Bazrafshan et al., 2016). The affect of equilibration time on the amount adsorbed was optimized at $\mathrm{pH}$ 6. Results are shown in Fig. 4.
All four metal ions have nearly same trend of equilibration. All four metal ions attained equilibration within 60 minutes and after 60 minutes the sorption remains nearly constant.

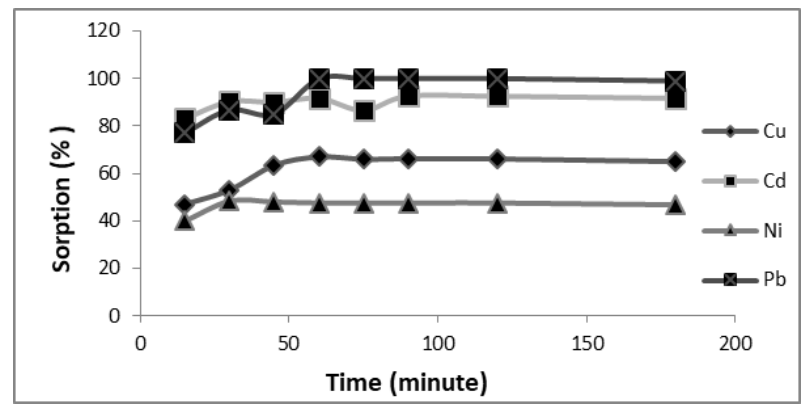

Figure 4. Uptake of $\mathrm{Cu}(\mathrm{II}), \mathrm{Cd}(\mathrm{II}), \mathrm{Ni}(\mathrm{II})$ and $\mathrm{Pb}$ (II) on okra leaves as a function of time

The kinetic data were evaluated by first order, second order rate equations (Khaskheli et al., 2014) as well as Elovich and Morris-Weber equations in order to understand the mechanism of adsorption. Following linearized equations were used:

$$
\begin{gathered}
\log \left(q_{e}-q_{t}\right)=\log q_{e}-\frac{k_{1} t}{2.303} \\
\frac{t}{q_{t}}=\frac{1}{k_{2} q e^{2}}+\frac{t}{q_{e}} \\
q_{t}=R_{d} \sqrt{t} \\
\frac{1}{q t}=\ln \frac{\alpha \beta}{\beta}+\frac{\ln t}{\beta} q
\end{gathered}
$$

Pseudo first order rate equation

Pseudo second order rate equation

Morris-Weber Equation

Elovich Equation

Where $k_{1}$ is the pseudo first and $k_{2}$ second order rate constant, $q_{e}$ is the amount of metal ions sorbed at equilibrium ( $\mathrm{mg} \mathrm{g}^{-1}$ ), and $\mathrm{q}_{\mathrm{t}}$ is amount of metal ions on the okra leaves at specified time $\left(\mathrm{mg} \mathrm{g}^{-1}\right)$. $R_{d}$ is he rate constant for intra particle diffusion. $\alpha$ is the initial sorption rate $(\mathrm{mg}$ $\left.\mathrm{g}^{-1} \mathrm{~min}^{-1}\right)$ and $\beta$ is desorption constant $\left(\mathrm{mg} \mathrm{g}^{-1} \mathrm{~min}^{-1}\right)$ during any one experiment.

Table 2 shows the kinetic parameters calculated by all four equations. As clear from Table $2 \mathrm{Ni}$ (II) and $\mathrm{Cd}(\mathrm{II})$ followed second order rate equation; whereas kinetic data of $\mathrm{Pb}$ (II) and $\mathrm{Cu}$ (II) followed first order rate equation. From these results it can be concluded that the mechanism of sorption of $\mathrm{Ni}(\mathrm{II})$ and $\mathrm{Cd}(\mathrm{II})$ is ion-exchange or chemisorption (Kumar et al., 2010) whereas, $\mathrm{Pb}$ (II) and $\mathrm{Cu}(\mathrm{II})$ follow the physical nature of sorption (Ranjan et al., 2009; Chen et al., 2008; Urik et al., 2009; Ho, 2006).

In case of Morris-Weber equation the straight lines of $\mathrm{Ni}(\mathrm{II}), \mathrm{Cd}(\mathrm{II})$ and $\mathrm{Pb}(\mathrm{II})$ did not pass through their origins which demonstrated that intra particle diffusion was not only the rate controlling step but other mechanisms were also involved in the rate determining step.

Elovich equation which was followed by $\mathrm{Ni}(\mathrm{II})$ and $\mathrm{Cd}(\mathrm{II})$, supported the chemisorption nature of the sorption reaction. 
Table 2. Kinetic parameters for the sorption of $\mathrm{Ni}(\mathrm{II}), \mathrm{Cu}(\mathrm{II}), \mathrm{Cd}(\mathrm{II})$ and $\mathrm{Pb}(\mathrm{II})$ on okra leaves

\begin{tabular}{|c|c|c|c|c|c|c|c|c|c|}
\hline \multirow[t]{2}{*}{ Metal } & \multicolumn{3}{|c|}{ Elovich } & \multicolumn{2}{|c|}{ Morris-weber } & \multicolumn{2}{|c|}{ first order eq. } & \multicolumn{2}{|c|}{ second order eq. } \\
\hline & $\begin{array}{c}\alpha \\
\left(\mathrm{mg} \mathrm{g}^{-1} \min ^{-1}\right)\end{array}$ & $\begin{array}{c}\beta \\
\left(\mathrm{g} \mathrm{mg}^{-1}\right)\end{array}$ & $\mathbf{r}$ & $\begin{array}{c}\mathbf{R}_{\mathrm{d}} \\
\left(\mu \mathrm{mol} \mathrm{g}^{-1} \mathrm{~min}^{-1}\right)\end{array}$ & $\mathbf{r}$ & $\begin{array}{c}K \\
\left(\mathrm{~min}^{-1}\right)\end{array}$ & $\mathbf{r}$ & $\begin{array}{c}\mathrm{K} \\
\left(\mathrm{g} \mathrm{mg}^{-1} \mathrm{~min}^{-1}\right)\end{array}$ & $r$ \\
\hline $\mathrm{Ni}(\mathrm{II})$ & 0.92 & 0.75 & 0.94 & 7.34 & 0.96 & - & - & 0.0072 & 0.98 \\
\hline $\mathrm{Cd}(\mathrm{II})$ & 35.96 & 2.07 & 0.98 & 1.36 & 0.97 & - & - & 0.044 & 0.99 \\
\hline $\mathrm{Pb}(\mathrm{II})$ & - & - & 0.97 & 2.36 & 0.97 & 0.0011 & 0.96 & - & - \\
\hline $\mathrm{Cu}(\mathrm{II})$ & - & - & - & - & - & 0.0015 & 0.94 & - & - \\
\hline
\end{tabular}

\subsection{Sorption Isotherm studies}

Isotherm study demonstrates the relationship between the amounts of metal ions present in solution and adsorbed on the surface of sorbent when equilibrium was established between these two phases. The affect of concentration on the amount of metal sorbed onto the surface was calculated and the data were evaluated using Langmuir, Freundlich (Khaskheli et al., 2016), D-R, Flory-Huggins and Halsey isotherm equations (Basar, 2006; Vijayaraghavan et al., 2006). All equations were analyzed in following linearized form:

$$
\begin{array}{cc}
\frac{C_{e}}{q_{e}}=\frac{1}{q_{\max }} C_{e}+\frac{1}{K_{L} q_{\max }} & \text { Langmuir } \\
\log q_{e}=\log K_{F}+\frac{1}{n} \log C_{e} & \text { Freundlich } \\
\ln q_{e}=\ln K_{D-R}-\beta \varepsilon^{2} & \text { Flory-Huggins } \\
\log \frac{\theta}{C_{i}}=\log K_{F H}+n_{F H} \log (1-\theta) & \\
\theta=1-\frac{C_{e}}{C_{i}} & \text { Halsey } \\
\operatorname{lnq} q_{e}=\frac{\operatorname{lnK} K_{H}}{n H}-\frac{\ln C_{e}}{n H} &
\end{array}
$$

Where $C_{e}$ is the equilibrium concentration of metal ions in solution ( $\left.\mathrm{mol} \mathrm{L}^{-1}\right), \mathrm{qe}$ is the amount of metal ions on surface $\left(\mathrm{mol} \mathrm{g}^{-1}\right), \mathrm{q}_{\max }$ is the maximum amount of ions sorbed, $\mathrm{K}_{\mathrm{L}}$ is the Langmuir constant related to the binding energy of solute, $K_{F}$ and $1 / n$ are Freundlich constants representing sorption capacity and sorption intensity, respectively; $\epsilon$ is polanyi potential and equal to $R \ln \left(1+1 / C_{e}\right), T$ is temperature and $R$ is general gas constant; $\beta$ is related to the mean free energy of sorption per mole of the sorbent when it is transferred from infinite distance in the solution to the surface of the solid by equation:

$$
E=\frac{1}{\sqrt{-2 \beta}}
$$

$\theta$ is degree of surface coverage, $n_{F H}$ is the Flory-Huggins model exponent represents the number of metal ions of solute occupy active sites of sorbent, $\mathrm{K}_{\mathrm{FH}}$ is the FloryHuggins model equilibrium constant is used to calculate the Gibbs free energy of spontaneity $\left(\Delta G^{\circ}\right)$ by following relationship.

$$
\Delta \mathrm{G}^{\circ}=-\mathrm{RT} \ln \mathrm{K}_{\mathrm{FH}}
$$

$\mathrm{K}_{H}$ is the Halsey constant and $\mathrm{n}_{H}$ is the exponent.

As shown in Table 3 Langmuir adsorption isotherm was nickel and cadmium envisages that all sites on sorbent are equal and uniform, there is no attraction between sorbed molecules and there is no steric hindrance between sorbed molecules and incoming ions and monolayer is formed at the maximum sorption capacity.

Copper and lead experimental data were fitted to Freundlich adsorption isotherm (Table 3). This isotherm describes the heterogeneity of the surface and formation of multilayers sorbed ions on the surface of the sorbent.

$D-R$ sorption isotherm on the basis calculated energy values define the nature of sorption of metal ions. In table 3 , energy of sorption range 8-15 for $\mathrm{Ni}(\mathrm{II})$ and $\mathrm{Cd}(\mathrm{II})$ demonstrates the ion exchange nature of sorption, while energy less than 8 for $\mathrm{Pb}$ (II) and $\mathrm{Cu}(\mathrm{II})$ shows the physical nature of sorption (Ranjan et al., 2009).The order of maximum metal uptakes calculated by $D-R$ isotherm was $\mathrm{Cu}^{2+}>\mathrm{Pb}^{2+}>\mathrm{Cd}^{2+}$ and $\mathrm{Ni}^{2+}, 453 \mathrm{mg} \mathrm{g}^{-1}, 81 \mathrm{mg} \mathrm{g}^{-1}, 13.82 \mathrm{mg} \mathrm{g}^{-}$ ${ }^{1}$ and $1 \mathrm{mg} \mathrm{g}^{-1}$ respectively.

Florry-Huggins model of isotherm discuss the mature of sorbent. Table 3 shows that there are number of metal ions $\left(\mathrm{n}_{\mathrm{FH}}\right)$ occupying sorption sites [copper (3.19), cadmium (1.87), lead (1.56) and nickel (1.3)] are present on the surface of the sorbent.

In case of Halsey isotherm high value of correlation coefficient $(r=0.94-0.99)$ indicates that data are well fitted to the isotherm and attests the heteroporous (macropores and micropores) nature of the sorbent (Oladoja et al., 2009).

\subsection{Thermodynamic Study}

The estimation of the feasibility and nature of the sorption process is evaluated by the calculation of thermodynamic parameters (Iftikhar et al., 2009). Thermodynamic parameters (Gibbs free energy, enthalpy change and entropy change) were calculated by using following equations.

$$
\begin{gathered}
\Delta \mathrm{G}=-\mathrm{RT} \operatorname{lnk\mathrm {C}} \\
\operatorname{lnk}_{\mathrm{c}}=\frac{\Delta \mathrm{S}}{\mathrm{R}}-\frac{\Delta \mathrm{H}}{\mathrm{RT}}
\end{gathered}
$$

The graph plotted Inkc against $1 / T$ gives linear curve. Entropy change $(\Delta \mathrm{S})$ and enthalpy change $(\Delta \mathrm{H})$ are determined from intercept and slope respectively. 
Table 3. Regression parameters for the Langmuir, Fruendlich, D-R Florry-Huggins and Halsey sorption isotherms by using okra leaves as sorbent

\begin{tabular}{|c|c|c|c|c|}
\hline Isotherm & $\mathrm{Cu}(\mathrm{II})$ & $\mathrm{Cd}(\mathrm{II})$ & $\mathrm{Ni}(\mathrm{II})$ & $\mathrm{Pb}(\mathrm{II})$ \\
\hline \multicolumn{5}{|l|}{ Langmuir } \\
\hline$q_{\max }\left(m g g^{-1}\right)$ & Not obeyed & 3.02 & 7.20 & Not obeyed \\
\hline$r$ & -- & 0.991 & 0.972 & -- \\
\hline \multicolumn{5}{|l|}{ Freundlich } \\
\hline $\mathrm{K}_{\mathrm{F}}\left(\mathrm{mg} \mathrm{g}^{-1}\right)$ & 43.75 & Not obeyed & Not obeyed & 102.0 \\
\hline$r$ & 0.971 & -- & -- & 0.970 \\
\hline \multicolumn{5}{|l|}{ D-R } \\
\hline $\mathrm{K}\left(\mathrm{mg} \mathrm{g}^{-1}\right)$ & 453.0 & 18.82 & 2.155 & 81.00 \\
\hline $\mathrm{E}\left(\mathrm{KJ} \mathrm{mole}^{-1}\right)$ & 7.58 & 15.4 & 11.8 & 7.20 \\
\hline$r$ & 0.982 & 0.987 & 0.971 & 0.977 \\
\hline \multicolumn{5}{|l|}{ Florry-Huggins } \\
\hline $\mathrm{K}_{\mathrm{FH}}\left(10^{4}\right)$ & 2.7 & 4.9 & 0.3 & 63.8 \\
\hline $\mathrm{n}_{\mathrm{FH}}$ & 3.19 & 1.87 & 1.3 & 1.56 \\
\hline$\Delta \mathrm{G}\left(\mathrm{KJ} \mathrm{mole}^{-1}\right)$ & -25.29 & -26.76 & -19.99 & -33.12 \\
\hline$r$ & 0.97 & 0.98 & 0.96 & 0.98 \\
\hline \multicolumn{5}{|l|}{ Halsey } \\
\hline $\mathrm{n}_{\mathrm{H}}$ & 0.63 & 0.52 & 0.45 & 0.44 \\
\hline $\mathrm{K}_{\mathrm{H}}\left(\mathrm{L} \mathrm{g}^{-1}\right)$ & 34.81 & 230.44 & 129.02 & 3011 \\
\hline$r$ & 0.99 & 0.98 & 0.99 & 0.94 \\
\hline
\end{tabular}

Table 4 shows that Gibbs free energy $(\Delta G)$ values of all metals are negative, means sorption reaction of metal ions on okra leaves sorbent was spontaneous (i.e sorption forces are quite strong to overcome the potential barrier). Increase of negative value with the increase of temperature favour the sorption process (Khaskheli et al., 2016). In other words it can be said that the degree of spontaneity increases with increasing the temperature (Thajeel, 2013). Positive values of entropy $(\Delta S)$ for $\mathrm{Ni}(\mathrm{II})$, $\mathrm{Cd}$ (II), $\mathrm{Pb}$ (II) and $\mathrm{Cu}$ (II) show that there was randomness of metal ions on the surface of sorbent during the process.

Table 4. Thermodynamic constants for the sorption of $\mathrm{Ni}(\mathrm{II}), \mathrm{Cd}(\mathrm{II}), \mathrm{Pb}$ (II) and $\mathrm{Cu}(\mathrm{II})$ on okra leaves at various temperatures

\begin{tabular}{|c|c|c|c|c|c|c|}
\hline Heavy metals & Temp. (K) & Inkc $\left(\mathrm{mg} \mathrm{g}^{-1}\right)$ & $\Delta G\left(\mathrm{~kJ} \mathrm{~mol}^{-1}\right)$ & $\Delta \mathrm{H}\left(\mathrm{kJ} \mathrm{mol}^{-1}\right)$ & $\Delta S\left(\mathrm{~kJ} \mathrm{~mol}^{-1} \mathrm{~K}^{-1}\right)$ & $\mathrm{R}\left(\mathrm{kJ} \mathrm{mol} \mathrm{mo}^{-1} \mathrm{~K}^{-1}\right)$ \\
\hline \multirow{3}{*}{$\mathrm{Ni}(\mathrm{II})$} & 293 & 1.21 & -2.94 & \multirow{3}{*}{17.09} & \multirow{3}{*}{0.07} & \multirow{12}{*}{$8.3143 \times 10^{-3}$} \\
\hline & 303 & 1.37 & -3.46 & & & \\
\hline & 313 & 1.65 & -4.32 & & & \\
\hline \multirow{3}{*}{$\mathrm{Cd}(\mathrm{II})$} & 293 & 1.58 & -3.86 & \multirow{3}{*}{8.77} & \multirow{3}{*}{0.04} & \\
\hline & 303 & 1.72 & -4.33 & & & \\
\hline & 313 & 1.82 & -4.72 & & & \\
\hline \multirow{3}{*}{$\mathrm{Pb}(\mathrm{II})$} & 293 & 1.73 & -4.22 & \multirow{3}{*}{22.04} & \multirow{3}{*}{0.09} & \\
\hline & 303 & 1.99 & -5.02 & & & \\
\hline & 313 & 2.31 & -6.02 & & & \\
\hline \multirow{3}{*}{$\mathrm{Cu}(\mathrm{II})$} & 293 & 1.99 & -4.85 & \multirow{3}{*}{40.43} & \multirow{3}{*}{0.15} & \\
\hline & 303 & 2.44 & -6.15 & & & \\
\hline & 313 & 3.06 & -7.95 & & & \\
\hline
\end{tabular}

\subsection{Column sorption studies of $\mathrm{CU}(\mathrm{II}), \mathrm{Cd}(\mathrm{II}), \mathrm{Ni}(\mathrm{II})$ and $\mathrm{Pb}(\mathrm{II})$} ions

For the evaluation of sorbent efficiency of okra leaves for the sorption of $\mathrm{Cu}(\mathrm{II}), \mathrm{Cd}(\mathrm{II}), \mathrm{Ni}(\mathrm{II})$ and $\mathrm{Pb}(\mathrm{II})$ ions was analyzed by employing the flow method containing column experiments.

\subsubsection{Effect of flow rate of sample}

These values also reflect the affinity of sorbent for particular metal ions. Positive values of enthalpy change $\Delta \mathrm{H}$ for all metals indicate that sorption process was an endothermic. These results support that sorption capacity of the adsorbent increases with the increasing of temperature (Surchi, 2011).

Similar trend of Gibbs free energy, entropy change and enthalpy change was observed with heavy metal adsorption on oak sawdust (Argun et al., 2007) and local activated carbon (Thajeel, 2013). 


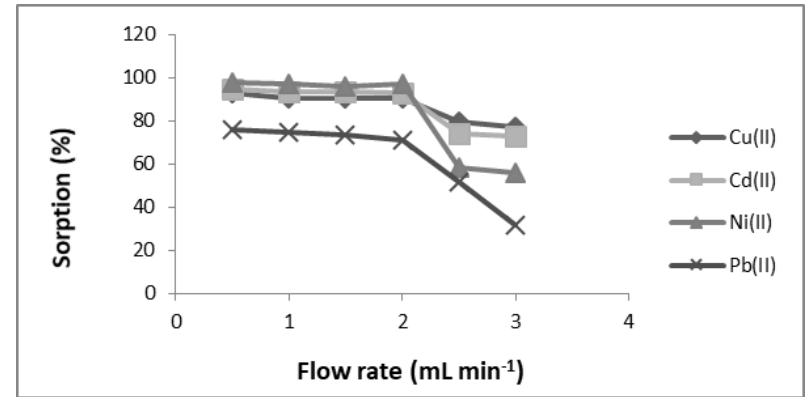

Figure 5. Effect of flow rate on the sorption of $\mathrm{Cu}(\mathrm{II})$, $\mathrm{Cd}(\mathrm{II}), \mathrm{Ni}(\mathrm{II})$ and $\mathrm{Pb}(\mathrm{II})$ ions on the okra leave sorbent

\subsubsection{Regeneration/Desorption Study}

To make sorption method more economical, it is necessary to desorb the adsorbed metals ions. Desorption process yields metals in concerted form; facilitate their disposal and restore sorbent for effective reuse (Ladeira and Ciminelli, 2004). For the regeneration of sorbent and recovery of metal ions, different mineral acids and bases were employed. The efficiency of leaching agents was evaluated with different concentrations (0.1-1M) and volumes $(1-5 \mathrm{~mL})$. The results indicated that $5 \mathrm{~mL}$ of $1 \mathrm{M}$ $\mathrm{H}_{2} \mathrm{SO}_{4}$ recovered $95-99 \%$ of metal ions.

\subsubsection{Limit of preconcentration and preconcentration factor}

The determination of preconcentration limit was based on the principle that the amount of metal ions was maintained constant $(10 \mu \mathrm{g})$ and volume of solution increased. $\mathrm{Cu}(\mathrm{II})$, $\mathrm{Cd}(\mathrm{II}), \mathrm{Ni}(\mathrm{II})$ and $\mathrm{Pb}(\mathrm{II})$ ions were quantitatively collected from the solutions having concentrations in the range of $0.04-0.1 \mu \mathrm{g} \mathrm{mL}$. The calculations revealed that preconcentration factor for $\mathrm{Cu}(\mathrm{II}), \mathrm{Cd}(\mathrm{II}), \mathrm{Ni}(\mathrm{II})$ and $\mathrm{Pb}(\mathrm{II})$ ions were 40, 20, 50 and 40 respectively.

\subsubsection{Breakthrough study (Total sorption capacity)}

Breakthrough study is related to the concentration of the effluent of column. Generally, when the effluent concentration reaches to $3-5 \%$ of influent is treated as breakthrough point. Solutions of $\mathrm{Cu}(\mathrm{II}) 7.9 \times 10^{-5} \mathrm{~mol} \mathrm{~L}^{-1}$, $\mathrm{Cd}$ (II) $4.4 \times 10^{-5} \mathrm{~mol} \mathrm{~L}^{-1}, \mathrm{Ni}$ (II) $8.5 \times 10^{-5}-\mathrm{mol} \mathrm{L}^{-1}$ and $\mathrm{Pb}$ (II)
$2.4 \times 10^{-5} \mathrm{~mol} \mathrm{~L}^{-1}$ were passed through columns. Fig. 6 shows that breakthrough curve is obtained at $75 \mathrm{~mL}$ for $\mathrm{Cu}(\mathrm{II}), 110 \mathrm{~mL}$ for $\mathrm{Cd}(\mathrm{II}), 130 \mathrm{~mL}$ for $\mathrm{Ni}$ (II) and $220 \mathrm{~mL}$ for $\mathrm{Pb}(\mathrm{II})$. Sharp jump in the percent sorption nearly in all metal ions favors the equilibrium.

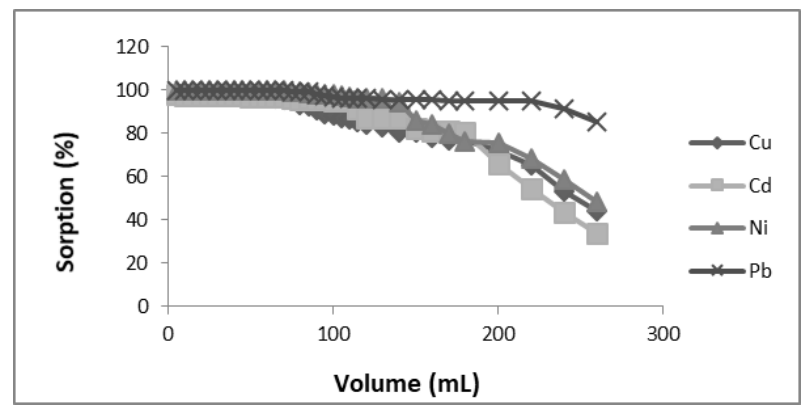

Figure 6. Breakthrough curve for the sorption of $\mathrm{Cu}(\mathrm{II})$, $\mathrm{Cd}(\mathrm{II}), \mathrm{Ni}(\mathrm{II})$ and $\mathrm{Pb}(\mathrm{II})$ ions on okra leaves sorbent

\section{BOD and COD of treated water samples}

Water is the main component for the regulating of the normal living system. Generally, the concentration of BOD (biochemical oxygen demand) is lower than the COD (chemical oxygen demand) in drinking water samples. EU (old EEC) recommended the $20-35 \mathrm{mg} \mathrm{L}^{-1}$ of COD in drinking water. After the treatment of contaminated water samples, BOD and COD were measured. The observed results showed that $\mathrm{Cu}(\mathrm{II}), \mathrm{Cd}(\mathrm{II}), \mathrm{Ni}(\mathrm{II})$ and $\mathrm{Pb}(\mathrm{II})$ treated water samples had BOD $0.77 \mathrm{mg} \mathrm{L}^{-1}, 2.44 \mathrm{mg} \mathrm{L}^{-1}, 1.33 \mathrm{mg} \mathrm{L}^{-}$ ${ }^{1}$ and $1.513 \mathrm{mg} \mathrm{L}^{-1}$ and COD $28 \mathrm{mg} \mathrm{L}^{-1}, 21 \mathrm{mg} \mathrm{L}^{-1}, 24 \mathrm{mg} \mathrm{L}^{-1}$ and $37 \mathrm{mg} \mathrm{L}^{-1}$ respectively.

\section{Application of the developed method}

The proposed sorbent was applied for the removal of $\mathrm{Ni}(\mathrm{II})$, $\mathrm{Cu}(\mathrm{II}), \mathrm{Cd}(\mathrm{II})$ and $\mathrm{Pb}$ (II) from drinking water samples. Table 5 shows the actual concentration of all four metal ions in drinking water before removal. Table 5 shows the efficiency of okra leaves for the removal of all four metal ions from real water systems at different concentration of these metal ions. It can be seen from Table 6 that okra leaves have good capacity to remove all four metal ions.

Table 5. Actual concentrations of $\mathrm{Ni}(\mathrm{II}), \mathrm{Cu}(\mathrm{II}), \mathrm{Cd}(\mathrm{II})$ and $\mathrm{Pb}(\mathrm{II})$ in different water samples

\begin{tabular}{|c|c|c|c|c|}
\hline Metal & $\begin{array}{l}\text { Conc: present in }{ }^{*}(\mathrm{~S} 1) \\
\mathrm{mg} \mathrm{L} \mathrm{L}^{-1}\end{array}$ & $\begin{array}{l}\text { Conc: present in }{ }^{*}(\mathrm{~S} 2) \\
\mathrm{mg} \mathrm{L} \mathrm{L}^{-1}\end{array}$ & $\begin{array}{l}\text { Conc: present in *(S3) } \\
\mathrm{mg} \mathrm{L}^{-1}\end{array}$ & $\begin{array}{c}\text { Conc: present in }{ }^{*}(\mathrm{~S} 4) \\
\mathrm{mg} \mathrm{L}^{-1}\end{array}$ \\
\hline $\mathrm{Cu}(\mathrm{II})$ & 0.26 & 0.29 & 0.300 & 0.25 \\
\hline $\mathrm{Cd}(\mathrm{II})$ & 0.29 & 0.01 & 0.007 & 0.00 \\
\hline $\mathrm{Ni}(I I)$ & 0.25 & 0.08 & 0.360 & 0.10 \\
\hline $\mathrm{Pb}(\mathrm{II})$ & 2.58 & 2.74 & 1.100 & 2.39 \\
\hline
\end{tabular}

*S1:- Hand pump water (Choudhary Mohammad Sadiq Chak 147, Taluka Sadiqabad, Distt: Rahimyar Khan), *S2:- Hand pump water (Basic Health Unit Manthar, Taluka Sadiqabad, Distt: Rahimyar Khan), *S3:- Tap water (Institute For Advanced Research Studies in Chemical Sciences, University Of Sindh, Jamshoro), *S4:- Hand Pump (Madarssa Dar-ul-uloom Manthar Taluka Sadiqabad Distt: Rahimyar Khan) 
Table 6. Removal of $\mathrm{Ni}(\mathrm{II}), \mathrm{Cu}(\mathrm{II}) \mathrm{Cd}(\mathrm{II})$ and $\mathrm{Pb}(\mathrm{II})$ from drinking water samples

\begin{tabular}{|c|c|c|c|c|c|c|c|c|c|c|c|c|c|}
\hline \multirow[t]{2}{*}{ Sample } & \multirow{2}{*}{$\begin{array}{c}\text { Amount added } \\
\left(\mathrm{mg} \mathrm{L}^{-1}\right)\end{array}$} & \multicolumn{4}{|c|}{ Total concentration $\left(\mathrm{mg} \mathrm{L}^{-1}\right)$} & \multicolumn{4}{|c|}{ \% Removal } & \multicolumn{4}{|c|}{ Residual Concentration $\left(\mathrm{mg} \mathrm{L}^{-1}\right)$} \\
\hline & & $\mathrm{Cu}$ & $\mathrm{Cd}$ & $\mathrm{Ni}$ & $\mathrm{Pb}$ & $\mathrm{Cu}$ & $\mathrm{Cd}$ & $\mathrm{Ni}$ & $\mathrm{Pb}$ & $\mathrm{Cu}$ & $\mathrm{Cd}$ & $\mathrm{Ni}$ & $\mathrm{Pb}$ \\
\hline S1 & 2.5 & 2.76 & 2.79 & 2.75 & 5.08 & 50.8 & 85.3 & 47.71 & 48.25 & 1.36 & 0.41 & 1.44 & 2.63 \\
\hline S1 & 5 & 5.26 & 5.29 & 5.25 & 7.58 & 64.29 & 96.03 & 57.94 & 65.44 & 1.88 & 0.21 & 2.21 & 2.62 \\
\hline S1 & 10 & 10.3 & 10.29 & 10.25 & 12.58 & 74.28 & 97.08 & 69.48 & 77.98 & 2.64 & 0.3 & 3.13 & 2.77 \\
\hline S2 & 2.5 & 2.79 & 2.507 & 2.585 & 5.244 & 42.29 & 88.03 & 50.1 & 32.88 & 1.61 & 0.3 & 1.29 & 3.52 \\
\hline S2 & 5 & 5.29 & 5.007 & 5.085 & 7.744 & 61.44 & 88.22 & 53.39 & 56.35 & 2.04 & 0.59 & 2.37 & 3.38 \\
\hline S2 & 10 & 10.3 & 10.01 & 10.09 & 12.74 & 65.4 & 89.71 & 57.46 & 72.06 & 3.56 & 1.03 & 4.29 & 3.56 \\
\hline S3 & 2.5 & 2.8 & 5.3 & 8.1 & 13.4 & 42.86 & 88.43 & 72.42 & 57.78 & 1.6 & 0.29 & 0.79 & 1.52 \\
\hline S3 & 5 & 5.3 & 10.3 & 15.6 & 25.9 & 57.74 & 91.21 & 75.4 & 69.67 & 2.24 & 0.44 & 1.32 & 1.85 \\
\hline S3 & 10 & 10.3 & 20.3 & 30.6 & 50.9 & 68.45 & 93.1 & 79.45 & 83.51 & 3.25 & 0.69 & 2.13 & 1.83 \\
\hline S4 & 2.5 & 2.75 & 2.5 & 5.251 & 7.751 & 53.47 & 90.4 & 53.1 & 43.73 & 1.28 & 0.24 & 1.22 & 2.75 \\
\hline S4 & 5 & 5.25 & 5 & 10.25 & 15.25 & 58.86 & 92 & 57.65 & 61.82 & 2.16 & 0.4 & 2.16 & 2.82 \\
\hline S4 & 10 & 10.3 & 10 & 20.25 & 30.25 & 64.59 & 92.2 & 60.59 & 74.65 & 3.63 & 0.78 & 3.98 & 3.14 \\
\hline
\end{tabular}

\section{Conclusion}

Present work explores the competitive sorption of $\mathrm{Ni}(\mathrm{II})$, $\mathrm{Cu}(\mathrm{II}), \mathrm{Cd}(\mathrm{II})$ and $\mathrm{Pb}(\mathrm{II})$ from aqueous solutions. It has been found that the okra leaves can efficiently be used for the removal of all four metal ions simultaneously. Kinetic, equilibrium and thermodynamic studies favour the adsorption of all four metal ions on okra leaves sorbent. EDX analysis confirms the presence of four metal ions on the surface of metal sorbed okra leaves. At the flow rate of

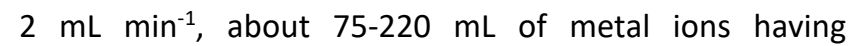
concentration $0.04-0.1 \mu \mathrm{g} \mathrm{mL}^{-1}$ can be passed through the column. Further, low values of COD and BOD of treated contaminated water encourage the application of the method. It can be concluded that okra leaves can be used as a replacement to existing expensive sorbents.

\section{References}

Ahmedna M., Marshall W.E., Husseiny A.A., Rao R.M. and Goktepe I. (2004), The use of nut shell carbons in drinking water filters for the removal of trace metals, Water Research, 38, 1062-1068.

Argun M.E., Dursum S., Ozdemir C. and Karatas M. (2007), Heavy metal adsorption by modified oak sawdust: Thermodynamics and Kinetics, Journal of Hazardous Materials, 141, 77-85.

Ashenef A. (2014), Essential and toxic metals in tea (Camellia sinensis) imported and produced in Ethopia, Foods Additives \& contaminants: Part B, 7, 30-36.

Basar C.A. (2006), Applicability of the various adsorption models of three dyes adsorption onto activated carbon prepared from waste apricot, Journal of Hazardous Materials, B135, 232-241.

Bazrafshan E., Mostafapour F.K. and Mahvi A.H. (2012b), Phenol removal from aqueous solutions using pishtachio-nut shell ash as a low cost adsorbent, Fresenius Environmental Bullettin, 21(10), 2962-2968.

Bazrafshan E., Ahmadabadi M. and Mahvi A.H. (2013a), Reactive Red-120 removal by activated carbon obtained from the cumin herb wastes, Fresenius Environmental Bullettin, 22(2a), 484-590.

Bazrafshan E., Ahmirian P., Mahvi A.H. and Ansari-Moghaddam A. (2016), Application of adsorption process for the phenolic compounds removal from aqueous environments: $A$ systematic review, Global NEST Journal, 18(1), 146-163.

Bozic D., Stankovic V., Gorgievski M., Bogdanovic G. and Kovacevic R. (2009), Adsorption of heavy metal ions by sawdust of deciduous trees, Journal of Hazardous Materials, 171, 684692.

Bulut Y. and Tez Z. (2007), Removal of heavy metals from aqueous solution by sawdust adsorption, Journal of Environmental Sciences, 19, 160-166.

Bulut Y. and Tez, Z. (2007), Adsorption studies on ground shells of hazelnut and almond, Journal of Hazardous Materials, 149, 35-41.

Chandio Z.A., Talpur F.N., Afridi H.I., Khan H., Khaskheli G.Q. and Khaskheli M.I. (2013), Online preconcentration of nickel(II) in textile effluent and soil samples by SDS coated alumina modified with dithizone mini-column coupled with FAAS, Analytical Methods, 5, 4425-4429.

Chandio Z.A., Talpur F.N., Khan H., Khaskheli G.Q. and Afridi H.I. (2013), Online preconcentration using surfactant coated alumina modified with 1, 5-diphenylthiocarbazone and determination of cadmium in environmental samples by flame atomic absorption spectrometry, Analytical Letters, 46, 1562-1572.

Chatterjee S.K., Bhattacharjee I. and Chandra G. (2010), Biosorption of heavy metals from industrial waste water by Geobacillus thermodenitrificans, Journal of Hazardous Materials, 175, 117-125.

Chen Y.N., Chai L.Y. and Shu Y.D. (2008), Study of arsenic (V) adsorption on bone char from aqueous solution, Journal of Hazardous Materials, 160, 168-172.

Evangelin C.D., Gunasekaran S.G. and Dharmendirakumar M. (2014), Preparation and characterization of chemically modified silk cotton hull activated carbon and its effects $\mathrm{Cd}$ (II) removal from aqueous solutions, Bioremediation Journal, 18, 81-92.

Farajzadeh M.A. and Monji A.B. (2004), Adsorption characteristics of wheat bran towards heavy metal cations, Separation and Purification Technology,

38, 197-207.

Feng D. and Aldrich C. (2004), Adsorption of heavy metals by biomaterials derived from the marine alga Ecklonia maxima, Hydromatallurgy, 73, 1-10.

Fiol N., Villaescusa I., Martinez M., Miralles N., Poch J. and Serarols J. (2006), Biosorption of aqueous $\mathrm{Pb} 2+, \mathrm{Cd} 2+$, and $\mathrm{Ni} 2+$ from aqueous solution by olive stone waste, Separation and Purification Technology, 50, 132-140.

Fuller C.C., Bargar J.R., Davis J.A. and Piana M.J. (2002), Mechanisms of uranium interactions with hydroxyapatite: 
implications for ground water remediation, Environmental Science and Technology, 36, 158-165.

Ho Y.S. (2006), Second-order kinetic model for the sorption of cadmium onto free fern: A comparison of linear and nonlinear methods, Water Research, 40, 119125.

Iftikhar A.R., Bhatti H.N., Hanif M.A. and Nadeem R. (2009), Kinetic and thermodynamic aspects of $\mathrm{Cu}$ (II) and $\mathrm{Cr}$ (III) removal from aqueous solutions using rose waste biomass, Journal of Hazardous Materials, 161, 941-947.

Jaeyoung C., Ju Y.L. and Jung-Seok Y. (2009), Biosorption of heavy metals and uranium by star fish and Pseudomonas, Journal of Hazardous Materials, 161, 157162.

Kefela M.I., Zouboulis A.I. and Matis K.A. (2000), Biosorption of cadmium ions by actinomycetes and separation by floation, Environmental Pollution, 104, 283-293.

Kim Y.Y., Dark S.K., Cho S.Y., Kim H.B., Kim Y.K.S.D. and Kim S.J. (2005), Adsorption of heavy metals by brewery biomass, Korean Journal of Chemical Engineering, 22, 91-98.

Khaskheli M.I., Memon S.Q., Siyal A.N. and Khuhawar M.Y. (2011), Use of orange peel waste for arsenic remediation of drinking water, Waste Biomass Valorization, 2, 423-433.

Khaskheli M.I., Memon S.Q., Parveen S. and Khuhawar M.Y. (2014), Citrus paradise: An effective bio-adsorbent for arsenic (V) remediation, Pakistan Journal of Analytical and Environmental chemistry, 15, 35-41.

Khaskheli M.I., Memon S.Q., Chandio Z.A., Jatoi W.B., Mahar M.T. and Khokhar F.M. (2016), Okra leaveas-Agricultural waste for the removal of $\mathrm{Cr}(\mathrm{III})$ and $\mathrm{Cr}(\mathrm{VI})$ from contaminated water, American Journal of Analytical Chemistry, 7, 395-409.

Kumar P.S., Vincent C., Kirthika K. and Kumar K.S. (2010), Kinetics and equilibrium studies of $\mathrm{Pb} 2+$ ion on removal from aqueous solution by use of nano-silversol-coated activated carbon, Brazilian Journal of Chemical Engineering, 27, 339-346.

Ladeira A.C.Q. and Ciminelli V.S.T. (2004), Adsorption and desorption of arsenic on an oxisol and its constituents, Water Research, 38, 2087-2094.

Li X., Tang Y., Cao X., Lu D., Luo F. and Shao W. (2008), Preparation and evaluation of orange peel cellulose adsorbents for effective removal of cadmium, zinc, cobalt and nickel, Colloids and Surfaces A: Physiochemical and Engineering Aspects, 317, 512-521.

Lu W.B., Shi J.J., Wang C.H. and Chang J.S. (2006), Biosorption of lead, copper and cadmium by an indigenous isolate Enterobacter sp. J1 possessing high heavy-metal resistance, Journal of Hazardous Materials, B13, 80-86.

Malakahmad A., Tan S. and Yavari S. (2016), Valorization of waste black tea as a low-cost adsorbent for nickel and zinc removal from aqueous solution, Journal of Chemistry, http:// dx.doi.org/10.1155/2016/5680983.

Martinez M., Miralles N., Hidalgo S., Fiol N., Villaescusa I. and Poch J. (2006), Removal of lead(II), and cadmium(II) from aqueous solutions using grape stalk waste, Journal of Hazardous Materials, B133, 203-211.

Memon S.Q., Bhanger M.I., Hasany S.M. and Khuhawar M.Y. (2007), The efficacy of nitrosonaphthol functionalized XAD-16 resin for the preconcentration/sorption of $\mathrm{Ni}$ (II) and $\mathrm{Cu}(\mathrm{II})$ ions, Talanta, 72, 1738-1745.

Memon S.Q., Hasany S.M., Bhanger M.I. and Khuhawar M.Y. (2005), Enrichment of $\mathrm{Pb}(\mathrm{II})$ ions using phthalic acid functionalized XAD-16 resin as a sorbent, Journal of Colloid and Interface Science, 291, 84-91.
Memon S.Q., Memon N, Shah S.W., Khuhawar M.Y. and Bhanger M.I. (2007), A green and economical sorbent for the removal of cadmium(II) ion, Journal of Hazardous Materials, B139, 116-121.

Oladoja N.A., Oladoja I.A., Idiaghe J.A. and Egbon E.E. (2009), Equilibrium isotherm analysis of sorption of congo red by palm kernel coat, Central European Journal of Chemistry, 7, 760-768.

Olajide S. (2009), Effect of pre-treatment on dying characteristics and kinetics of okra (Abelmoschus esculentus L. Moench) slices, International Journal of Food Engineering, 5, 1-11.

Oliveira W.E., Franca A.S., Oliveira L.S. and Rocha S.D. (2008), Untreated coffee husks as biosorbents for the removal of heavy metals from aqueous solutions, Journal of Hazardous Materials, 152, 1073-1081.

Panda G.C., Das S.K. and Guha A.K. (2008), Biosorption of cadmium and Nickel by functionalized husk of Lathyrus Sativus, Colloids and Surfaces B: Biointerfaces, 62, 173-179.

Parsad M.N.V. and Freltas H. (2000), Removal of toxic metals from solution by leaf, stem and root phytomass of Querus ilex (holly Oak), Environmental Pollution, 110, 277-283.

Pehlivan E., Altun T. and Parlayici S. (2009), Utilization of barley straws as biosorbents for $\mathrm{Cu}(\mathrm{II})$ and $\mathrm{Pb}(\mathrm{II})$ ions, Journal of Hazardous Materials, 164, 982-986.

Ranjan D., Talat M. and Hasan S.H. (2009), Biosorption of arsenic from aqueous solution by using agricultural residue 'rice polish', Journal of Hazardous Materials, 166, 1050-1059.

Rao M.M., Ramana D.K., Seshaiah K., Wang M.C. and Chien C.S.W. (2009), Removal of some metal ions by activated carbon prepared from phaseolus aureus hulls, Journal of Hazardous Materials, 166, 1006-113.

Rojas G., Silva J. and Flores J.A. (2005), Adsorption of chromium on cross linked chitosan, Separation and Purification Technology, 44, 31-36.

Sassi M., Bestani B., Said A.H., Benderdouche N. and Guibal E. (2010), Removal of heavy metal ions from aqueous solutions by a local sludge as a biosorbent, Desalination, 262, 243-250.

Silverstein R.M. and Webster F.X. (1998), Spectrometric identification of Organic Compounds. 6th ed. John Wiley \& Sons.

Sobecka E. (2001), Changes in the iron level in the organs and tissues of wells catfish, slurus glanis I. caused by nickel, Acta Lchthyological Piscatoria, 31, 127-143.

Southichak B., Nakano K., Munehiro Chiba N. and Nisbimura O. (2006), Phragmites australis: A noval biosorbent for the removal of heavy metals from aqueous solution, Water Research, 40, 2295-2302.

Suman V.B., Meloa J.S., Chaugule B.B. and D'Souza S.F. (2008), Biosorption characteristics of uranium (VI) from aqueous medium onto Catenellarepens, a red algae, Journal of Hazardous Materials, 158, 628-635.

Surchi M.M.S. (2011), Agricultural wastes as low caste adsorbents for $\mathrm{Pb}$ removal: kinetics, equilibrium and thermodynamics, International Journal of Chemistry, 3, 53-77.

Thajeel A.S. (2013), Isotherm, kinetic and thermodynamic of adsorption of heavy metal ions onto local activated carbon, Aquatic Science and Technology, 1, 53-77.

Urik M.P., Littera S.J., Kolencik M. and Cernasky S. (2009), Removal of arsenic ( $V$ ) from aqueous solutions using modified sawdust of spruce (Picea abies): kinetics and isotherm studies, 
International Journal of Environmental Science and Technology, 6, 451-456.

Vijayaraghavan K., Padmesh T.V.N., Palanivelu K. and Velan M. (2006), Biosorption of nickel(II) ions onto Sargassum wightii. Application of two-parameter and three- parameter isotherm models, Journal of Hazardous Materials, B133, 304-308.

Wong K.K., Lee C.K., Low K.S. and Haron M.J. (2003), Removal of $\mathrm{Cu}$ and $\mathrm{Pb}$ by tartaric acid modified rice husk from aqueous solutions, Chemosphere, 50, 23-28.

W.H.O, (2011), Guidelines for drinking water-quality, $4^{\text {th }} \mathrm{Ed}$, Geneva 27, Switzerland 